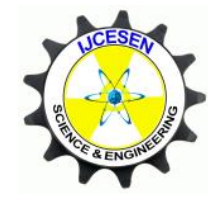

Copyright $\mathbb{C}$ IJCESEN
International Journal of Computational and

Experimental $\boldsymbol{S}$ cience and Engineering

(IJCESEN)

Vol. 4-No.2 (2018) pp.14-22

http://dergipark.gov.tr/ijcesen

Research Article

\title{
Engineering Properties of Eğirdir-Kızldağ Harzburgitic Peridotites in Southwestern Turkey
}

\author{
Züheyr KAMACI ${ }^{1 *}$, Pelin ÖZER ${ }^{2}$ \\ ${ }^{1}$ Süleyman Demirel Üniversity, Faculty of Engineering, Geophysics Department, 32200, Isparta-Turkey \\ ${ }^{2}$ Süleyman Demirel Üniversity, Graduate School of Applied and Naturel Sciences, Geophysics Dep., Isparta-Turkey \\ * Corresponding Author : zuheyrkamaci@sdu.edu.tr \\ ORCID: 0000-0002-2331-0162
}

(First received 1 November 2017 and in final form 17 April 2018)

\section{Keywords}

serpantine

rock mechanics

UPV

UCS

\begin{abstract}
In rock mechanics, various methods are available to detect the rock properties. The aim of this study is to determine physical and mechanical properties of the serpentinized ultrabasic rocks such as Eğirdir-Kızıldağ Harzburgitic Peridotites. The serpentinized ultrabasic rocks are commonly used for architecture and the ground under road bases in many areas and also widely used for indoor elements such as tables, pilasters and ornaments of different kinds. In this study, geophysical and geotechnical tests including $\mathrm{P}$ and $\mathrm{S}$ - wave velocities, rigidity modulus, Poisson ratio, elasticity modulus, bulk modulus, natural period, safe bearing capacity and bedding coefficient were performed on nine rock samples, collected from different areas. Geophysical and geotechnical studies were carried out both parallel and perpendicular to foliation planes of the cubic samples. Ultrasonic P-Wave Velocity (UPV), Uniaxial Compressive Strength (UCS), volumetric water contents, effective porosity, unit volume weight, density and weight of all samples were calculated. Finally, statistical relations among the measured parameters were established by using regression analysis.
\end{abstract}

\section{Introduction}

Geologically, rocks are divided into three classes such as magmatic, metamorphic and sedimentary rocks. However, rock classifications used in engineering studies are very different to geological classifications, because for engineering studies durability and sensitivity gain importance rather than the source of the rocks. Rocks classified as basic and ultrabasic have gained significant value in the natural rock sector in recent years. As a result with demand reaching significant levels, in addition to the sectoral name of magmatic rocks, some terms related to mineralogy and petrography have entered the natural stone sector. Some rock properties were determined and defining the correlations between them, provides significant benefits especially in terms of feasibility for engineering and interior-exterior decorative work. As explained in the related standards for determine uniaxial compressive strength of rocks (UCS) which is important for engineering classification of rocks, smooth-cut cube-shaped rock samples are required. Though many studies like [1-16] have been completed to determine the mechanical and engineering properties of rocks with the UCS test, these studies were only completed on ultrabasic rocks with very little serpentinization [17-27]. In this research the engineering and mechanical properties of serpentinized ultrabasic rocks called the "Eğirdir Kızıldağ Harzburgite" [28] outcropping south of Isparta-Pazarköy in southwest Turkey were determined with geological and geophysical methods.

In addition to geophysical studies like seismic refraction, electrical resistivity and micro tremor, cubic samples obtained from rock blocks in the field had uniaxial compressive strength (UCS), ultrasonic seismic velocity (UPV), saturated and dry volume weight, volume and weight water absorption, density and porosity experiments performed both perpendicular and parallel to 
foliation. The data obtained from the experiments were statistically analyzed with a simple regression method and interpreted.

\section{Geology of The Investigation Area}

The study [29] was focused on the maficultramafic rocks on the north wing of the Antalya complex in Southwest Turkey in terms of geological, chemical and geodynamic properties (Fig. 1).

The oldest unit in the area covered by the study is the Anamas-Akseki Platform which is basically comprised of limestone and dolomites. The sequence from bottom to top is as follows. The oldest unit of the platform is upper ManianRhaetian Menteşe dolomites. At the top the
Menteşe dolomites pass up into upper Lias-Upper Cretaceous Alakilise limestones. Above these limestones the dominant lithologies are micritic limestone, occasional shale and claystones. Then there are the Upper Cretaceous Eşekini limestones [30]. The Anamas-Akseki platform comprises Campanian-Maastrictian age limestones and ends with the Anamasdağ limestones [31]. Above these are sedimentary rock units of the Pazarköy Group reflecting different basin conditions brought together by tectonic relations and again volcanic rocks from different tectonic environments (Akpınar Tepe volcanics, Havutlu volcanics) and Kızıldağ peridotites, Dulup limestones, and Öbektaş formation tectonically emplaced (Fig. 1).

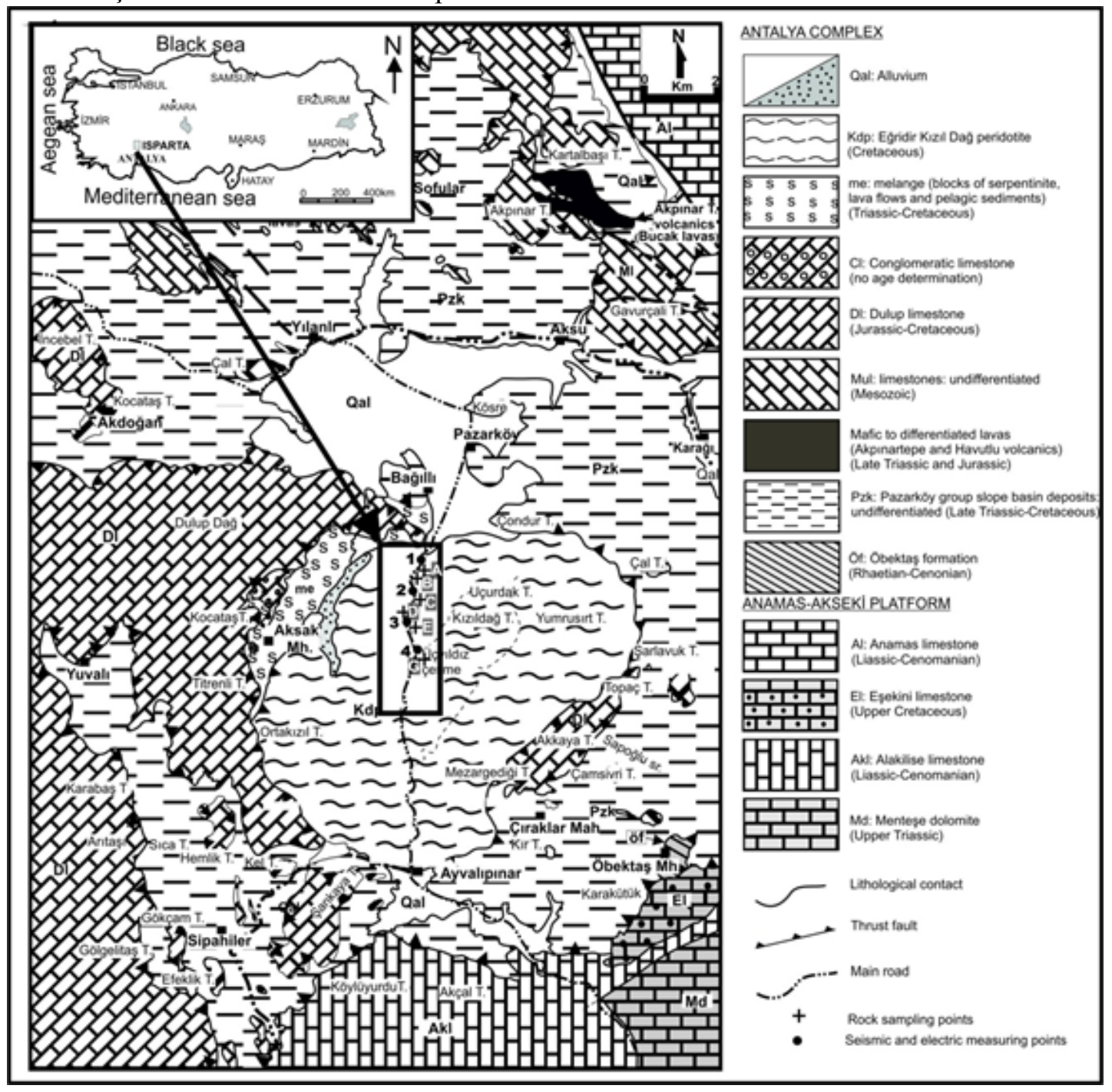

Figure 1. Location and geological map of the study area (modified from [29]) 
Kızıldağ Peridotites are mainly harzburgitic peridotites with pyroxenite and isolated diabase dykes cutting them and occasional lens-shaped dunites within the harzburgites. The peridotites generally have weathered surfaces of brown, yellowish-brown and greenish-brown, with fresh broken surfaces dark green, black-green, and yellowish-green color tones (Fig. 2).

These harzburgites contain magmatic foliation and there are pyroxene minerals or pyroxene-rich thin layers parallel to this banding [29]. The mineralogical composition of these rocks, and the scarcity or abundance of the minerals, is very important in terms of naming the rocks, the cutting and polishing of the rocks, trade value and even block production. When mineralogical properties of rock samples used in experiments is examined, in places with magmatic foliation observed mineralogical and petrography properties were investigated in thin sections obtained with two orientations, perpendicular and parallel to the foliation (Fig. 3).
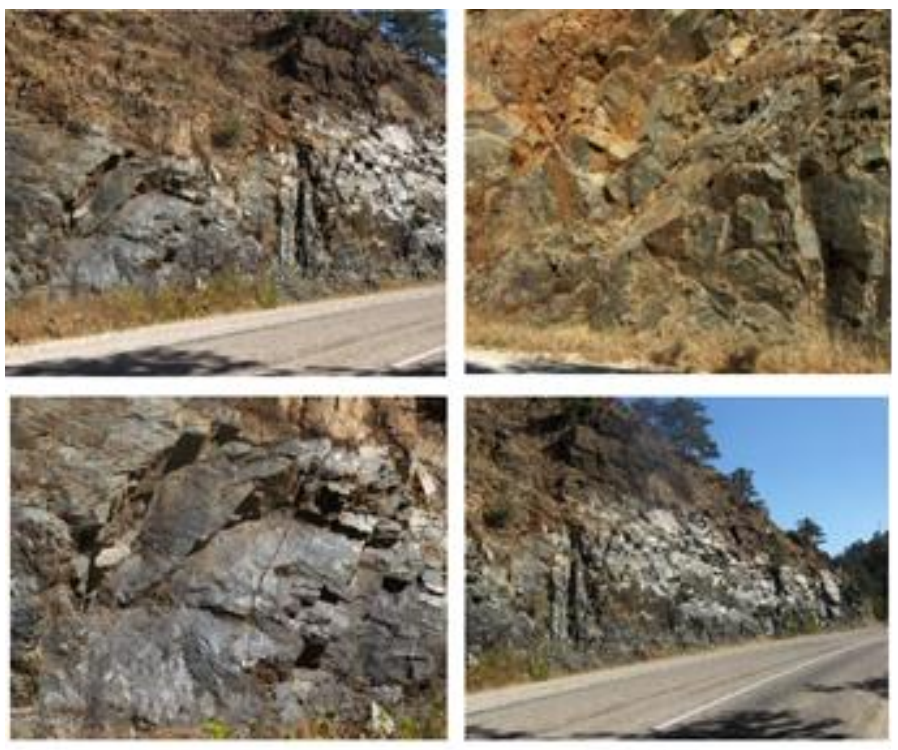

Figure 2. Serpentinized ultrabasic rocks exposed in SW Turkey (Isparta-Eğirdir-Pazarköy).
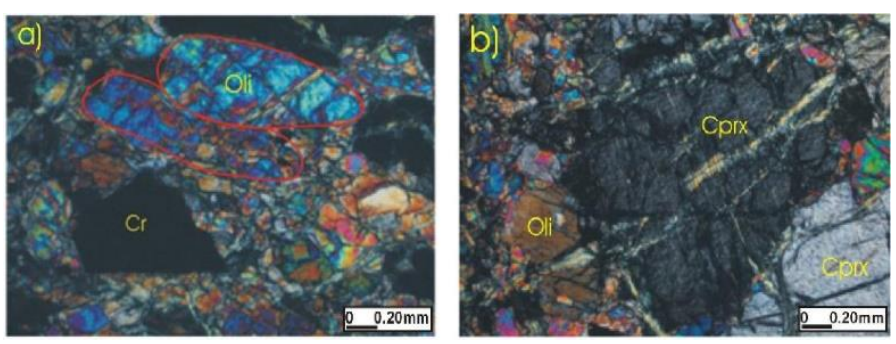

Figure 3. Section view of the harzburgite forming minerals (Olivine, Clinopyroxene and Cromite), a) along foliation, b) across foliation.

The basic minerals in the rock are olivine and clinopyroxenes. Accessory minerals include chromite. The majority of holocrystalline texture in the rock is comprised of olivine. Olivines with anhedral and semieuhedral crystals are altered and serpentinized at the edges and on cleavage planes.
As a result olivines display sieve texture. Crystals are medium-large size. Clinopyroxene minerals are represented by enstatite. These are generally large crystals with some medium size. Like olivines these appear serpentinized. Additionally polysynthetic twinning is present. The most important difference between sections perpendicular to foliation and those parallel to foliation is in the shape of the minerals. In sections perpendicular to foliation, minerals are generally have round or ellipsoid shape, while in sections parallel to foliation they are lengthened in a particular direction. Medium grain size chromites are semi-euhedral and anhedral and opaque. Fig.3 shows oli: olivine, cprx: clinopyroxenes and cr: chromite.

\section{Material and Methods}

This study was conducted covering the South of IspartaEğirdir-Pazarköy was completed in two stages as field and laboratory studies.

\subsection{Field Studies}

In the field, geophysical seismic refraction, microtremor and electrical resistivity studies were completed at five different points (Fig. 1). Seismic refraction and electrical resistivity studies were used to obtained the dynamic properties of serpentinized ultrabasic rocks. Seismic refraction data was recorded on a 12 channel WZG-48 model seismograph. The $\mathrm{P}$ and $\mathrm{S}$ seismic velocities of the layers were calculated using the Esos-Seisimager evaluation program. Using the experimental equations found in studies [32-33], [25] and [34], the elasticity modulus of rocks was determined using $\mathrm{P}$ and $\mathrm{S}$ seismic velocities values. The mean calculated $P$ and $S$ wave velocities were given in Table 1.

Here $\mathrm{P}$ and $\mathrm{S}$ seismic wave velocities are $\mathrm{V}_{\mathrm{P}}$ and $\mathrm{V}_{\mathrm{S}}$, the dry unit weight is DUW, Poisson's ratio is $v$, the rigidity modulus is $\mathrm{G}$, the elasticity modulus is $\mathrm{E}$, the bulk modulus is $\mathrm{k}$, the safety bearing capacity is qs, the bearing coefficient is $\mathrm{K}_{S}$ and The natural period is $\mathrm{T}_{\mathrm{o}}$. The natural period of the ground at the points where seismic measurements were taken was measured with a CMG-6TD Broad-Band microtremor instrument. At each point a 30 minute measurement duration used with $100 \mathrm{~Hz}$ sampling interval with measurements taken in a 25 second window with 5\% overlap with mean values taken from the obtained results.

Electric resistivity data was obtained with a Schlumberger electrode array Vertical Electrical Sounding (VES) technique (Fig. 1). Mean 60 meters was chosen as the current electrode interval (AB). VES curves were assessed and interpreted with the IP2WIN computer iteration technique.

\subsection{Laboratory Studies}

According to [35] and [36] standards, uniaxial compressive strength experiments were completed on $2 \mathrm{x}$ $2 \times 2$ inch, or $51 \times 51 \times 51 \mathrm{~mm}$, cubic rock samples. 


\subsubsection{Ultrasonic Pulse Velocity Measurements (UPV)}

Ultrasonic pulse velocity (UPV) tests were conducted using Pundit Plus tester consist of placing two piezoelectric transducers on two opposite sides of the samples and the travel time which is through the exact distance between the transducers was measured. UPV test was conducted on cubic samples of $51 \times 51 \times 51 \mathrm{~mm}$. The surface of the cubic specimens was polished and used stiffer grease for good coupling. Experiments were initially conducted on dry samples. The same experiments were then repeated after samples were saturated with water and were given in Table 2 . The test results of studies by [37], [12] and [25] showed that seismic velocity values parallel to foliation were always higher than those perpendiculars to foliation and this situation is due to the anisotropic properties of the rock. Based on this, the Pwave velocities $(\mathrm{Vp})$ of cubic rock samples in this study were separately determined according to [38] standards , with a PUNDIT7-UPV E48 brand seismic velocity instruments and same results were obtained from the experiments.

\subsection{Geotechnical Studies}

Cubic samples obtained from four different locations were made with polished surfaces. A total of 6 different groups of samples were obtained from the same location and numbered accordingly (A1- B1- B2- B3- C1- D1- E1- E2G1) for a total of 66 rock samples. Physical properties such as density, unit volume weight, effective porosity, mass and volume water absorption rates and seismic velocity were determined. Density experiments were completed according to standard [39], 3 times on each sample and arithmetic mean of assessments were taken.

Some physical properties of rocks such as dry unit volume weight, water absorption capacity (by volume and by weight), effective and total porosity were determined all this properties of rocks which were performed in dry conditions were determined using saturation and buoyancy techniques according to related standarts such as recommended by [36], [40] and [38].

\subsubsection{Uniaxial Compressive Strength Experiment (UCS)}

The uniaxial compressive strength (UCS) of the specimens was determined according to related standard [38] and by subjecting each specimen to incremental loading at a nearly constant rate with the 200 ton loading capacity hydraulic press [41].

\section{Results and Discussion}

All physical and mechanical properties of serpentinized ultrabasic rock samples were given in Table 2. To determine a range of correlations between these results, the least squares regression analysis method was used. to This regression analysis was carried out to determine correlations between UCS and Wn, UCS and n, UCS and DUW, UCS and $\gamma_{s}$, Wn and Vp, n and Vp, DUW and Vp, $\gamma_{\mathrm{s}}$ and $\mathrm{Vp}$ and UCS and Vp perpendicular and parallel to foliation and degrees of fit are shown with the graphs (Fig. 4-12).
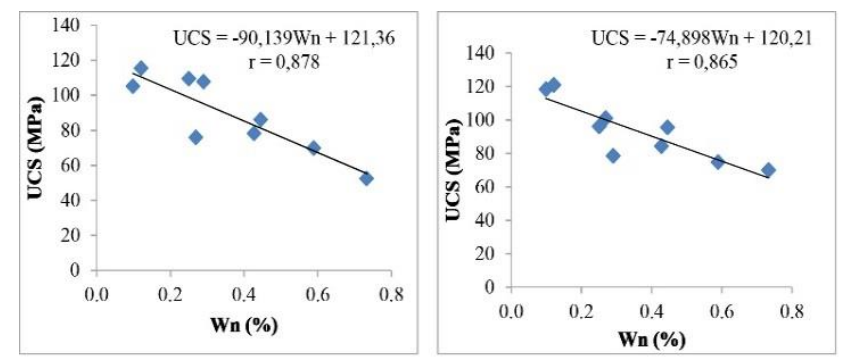

Figure 4. Scatter plot of UCS against Water apsorption (Wn) for cubic specimens with respect to a) across foliation, $b$ ) along foliation.

All correlations between the engineering properties of rocks according to UCS and Vp were given together in Table 3. Accordingly the highest correlation coefficient (r) was 0.95 found between DUW and $V_{P}$ of samples perpendicular to foliation. For samples parallel to foliation the correlation coefficients for $\mathrm{Wn}$ and $\mathrm{V}_{\mathrm{P}}$ and $\mathrm{n}$ and $\mathrm{V}_{\mathrm{P}}$ were about 0.94 . The lowest correlation coefficient for perpendicular samples was 0.80 for DUW and UCS and 0.78 for $\gamma_{\mathrm{s}}$ and UCS. Similarly there there was a good negative linear correlation for UCS and Wn and UCS and $\mathrm{n}$ perpendicular and parallel to foliation (Fig. 4-5). Accordingly as $\mathrm{Wn}$ or $\mathrm{n}$ values increase in these rock samples, the UCS value decreased. There was a positive linear correlation between UCS and DUW and UCS and $\gamma_{\mathrm{s}}$ perpendicular and parallel to foliation (Fig. 6-7). As DUW or density $\left(\gamma_{\mathrm{s}}\right)$ increase in rock samples, the UCS value increases. There was adverse linear correlation between $V_{P}$ and $\mathrm{Wn}$ and $\mathrm{V}_{\mathrm{P}}$ and $\mathrm{n}$ perpendicular and parallel to foliation (Fig. 8-9). Here as $\mathrm{Wn}$ and $\mathrm{n}$ increase, the $\mathrm{V}_{\mathrm{P}}$ seismic velocity value decreases. When the $\mathrm{n}$ value is equivalent to effective porosity, it can be said there is a linear correlation between porosity and seismic velocity. There is a positive linear correlation between $V_{P}$ and DUW and $V_{P}$ and density $\left(\gamma_{\mathrm{s}}\right)$ perpendicular and parallel to foliation (Fig. 10-11). As the density and unit volume weight (DUW) increase, the seismic velocity value increases.

As shown in Fig. 12, there is a positive linear correlation between UCS and $V_{P}$. In other words as seismic velocity increases, the UCS value increases. As a result, very significant relations was determined between UPV $\left(=V_{P}\right)$ and mechanical and engineering properties of the serpentinized ultrabasic rocks.

\section{Conclusions}

The most important purpose of this work was to figure out the physical and mechanical properties of rocks, as well as dynamic engineering properties, of serpentinized ultrabasic rocks. 


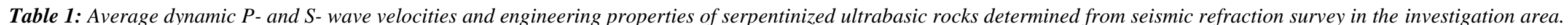

\begin{tabular}{|c|c|c|c|c|c|c|c|c|c|c|}
\hline $\begin{array}{l}\text { Seismic } \\
\text { Locations }\end{array}$ & $\begin{array}{c}\mathrm{Vp} \\
{[\mathrm{m} / \mathrm{s}]}\end{array}$ & $\begin{array}{c}\mathrm{Vs} \\
{[\mathrm{m} / \mathrm{s}]}\end{array}$ & $\begin{array}{c}\text { DUW } \\
{[\mathrm{kN} / \mathrm{m} 3]} \\
\text { DUW }=\left(0.002 * \mathrm{~V}_{\mathrm{p}}\right) \\
+16\end{array}$ & $\begin{array}{l}\mathrm{v} \\
\mathrm{v} \\
=\frac{\mathrm{V}_{\mathrm{p}}^{2}-2 * \mathrm{~V}_{\mathrm{s}}^{2}}{2 *\left(\mathrm{~V}_{\mathrm{p}}^{2}-\mathrm{V}_{\mathrm{s}}^{2}\right)}\end{array}$ & $\begin{array}{c}\mathrm{G} \\
{[\mathrm{Gpa}]} \\
=\frac{\mathrm{DUW} * \mathrm{~V}_{\mathrm{s}}^{2}}{100}\end{array}$ & $\begin{array}{l}\mathrm{E} \\
\mathrm{E} \\
=2 *(1+\mathrm{Gpa}] \\
=2 \mathrm{G}\end{array}$ & $\begin{array}{c}\mathrm{K} \\
\mathrm{k}=\frac{2 *(1+\mathrm{v})}{3 *(1-2 * \mathrm{v} / \mathrm{m} 3]} \\
* \mathrm{G}\end{array}$ & $\begin{array}{l}\text { To } \\
{[\mathrm{s}]}\end{array}$ & $\begin{array}{cc}\mathrm{qs} & \\
{[\mathrm{kPa}]} & \\
\mathrm{q}_{\mathrm{s}}=0.024 * \mathrm{DUW} \\
& * \mathrm{~V}_{\mathrm{s}}\end{array}$ & $\begin{array}{l}\mathrm{Ks} \\
{[\mathrm{kN} / \mathrm{m} 3]} \\
\mathrm{K}_{\mathrm{s}} \\
=40 * \frac{\mathrm{V}_{\mathrm{p}}}{\mathrm{V}_{\mathrm{s}}} \\
* \mathrm{q}_{\mathrm{s}} \\
* 19.99\end{array}$ \\
\hline $\begin{array}{l}1 \\
2 \\
3 \\
4\end{array}$ & $\begin{array}{l}4701 \\
4317 \\
4590 \\
5549\end{array}$ & $\begin{array}{l}2582 \\
2213 \\
2489 \\
2828\end{array}$ & $\begin{array}{l}25,40 \\
24,63 \\
25,18 \\
27,10\end{array}$ & $\begin{array}{l}0,28 \\
0,32 \\
0,29 \\
0,32\end{array}$ & $\begin{array}{l}16,93 \\
12,06 \\
15,59 \\
21,67\end{array}$ & $\begin{array}{l}42,34 \\
31,83 \\
40,22 \\
57,21\end{array}$ & $\begin{array}{l}32,90 \mathrm{E}+08 \\
29,42 \mathrm{E}+08 \\
31,62 \mathrm{E}+08 \\
53,47 \mathrm{E}+08\end{array}$ & 0,09 & $\begin{array}{l}1573,98 \\
1308,14 \\
1504,15 \\
1839,33\end{array}$ & $\begin{array}{l}2291427 \\
2040458 \\
2217950 \\
2885810\end{array}$ \\
\hline $\begin{array}{l}\text { Average } \\
\text { Standard } \\
\text { deviation }\end{array}$ & 346,38 & 185,89 & 0,70 & 0,02 & 2,63 & 6,68 & 3,11 & - & 149,45 & 232914,7 \\
\hline
\end{tabular}

Table 2: Summary of results of dry and saturated unit weight, water absorption and effective porosity, wave velocity, and

\begin{tabular}{|c|c|c|c|c|c|c|c|c|c|}
\hline \multirow[b]{2}{*}{$\begin{array}{c}\text { Sample } \\
\text { No }\end{array}$} & \multirow[b]{2}{*}{$\begin{array}{c}\text { Water } \\
\text { absorption } \\
\mathrm{W}_{\mathrm{n}}[\%]\end{array}$} & \multirow[b]{2}{*}{$\begin{array}{c}\text { Effective } \\
\text { porosity } \\
\text { n [\%] }\end{array}$} & \multirow[b]{2}{*}{$\begin{array}{c}\text { Dry Unit } \\
\text { Weight } \\
\text { DUW } \\
{\left[\mathrm{g} / \mathrm{cm}^{3}\right]}\end{array}$} & \multirow[b]{2}{*}{$\begin{array}{c}\text { Saturated } \\
\text { unit } \\
\text { weight, } \gamma \mathrm{s} \\
{\left[\mathrm{g} / \mathrm{cm}^{3}\right]}\end{array}$} & \multirow[b]{2}{*}{$\begin{array}{c}\text { Total } \\
\text { porosity } \\
\text { Pt [\%] }\end{array}$} & \multicolumn{2}{|c|}{ Across Foliation } & \multicolumn{2}{|c|}{ Along Foliation } \\
\hline & & & & & & $\begin{array}{c}\mathrm{Vp} \\
{[\mathrm{m} / \mathrm{s}]}\end{array}$ & $\begin{array}{c}\text { UCS } \\
{[\mathrm{MPa}]}\end{array}$ & $\begin{array}{c}\mathrm{Vp} \\
{[\mathrm{m} / \mathrm{s}]}\end{array}$ & $\begin{array}{c}\text { UCS } \\
{[\mathrm{MPa}]}\end{array}$ \\
\hline $\mathrm{A} 1$ & 0,59 & 1,75 & 2,98 & 3,15 & 0,05 & 5564 & 69,99 & 6063 & 74,93 \\
\hline B1 & 0,43 & 1,30 & 3,04 & 3,15 & 0,04 & 5907 & 78,34 & 6433 & 84,41 \\
\hline B2 & 0,27 & 0,83 & 3,11 & 3,25 & 0,04 & 5913 & 76,03 & 7853 & 101,21 \\
\hline B3 & 0,45 & 1,36 & 3,06 & 3,18 & 0,04 & 5683 & 86,24 & 6605 & 95,56 \\
\hline $\mathrm{C} 1$ & 0,73 & 1,94 & 2,65 & 2,69 & 0,01 & 4416 & 52,64 & 5723 & 70,04 \\
\hline D1 & 0,29 & 0,88 & 3,05 & 3,19 & 0,04 & 5933 & 107,88 & 6852 & 78,61 \\
\hline E1 & 0,10 & 0,33 & 3,29 & 3,35 & 0,02 & 7429 & 105,30 & 8009 & 118,42 \\
\hline E2 & 0,12 & 0,40 & 3,27 & 3,41 & 0,04 & 7435 & 115,64 & 7923 & 121,05 \\
\hline G1 & 0,25 & 0,78 & 3,10 & 3,21 & 0,03 & 6473 & 109,52 & 7024 & 96,18 \\
\hline $\begin{array}{l}\text { Average } \\
\text { Standart } \\
\text { Devition }\end{array}$ & 0,21 & 0,56 & 0,19 & 0,20 & 0,01 & 941 & 21,58 & 835 & 27,27 \\
\hline
\end{tabular}




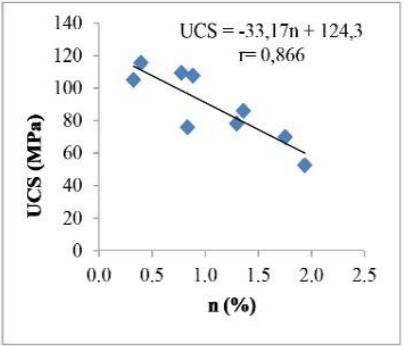

a

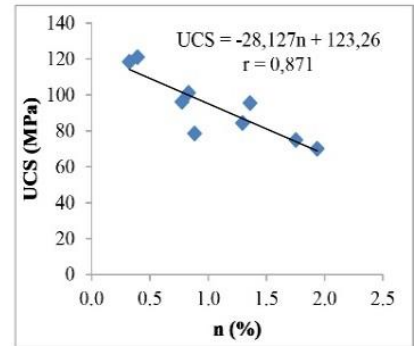

b
Figure 5. Scatter plot of UCS against Effective porosity (n) for cubic specimens with respect to a) across foliation, $b$ ) along foliation.

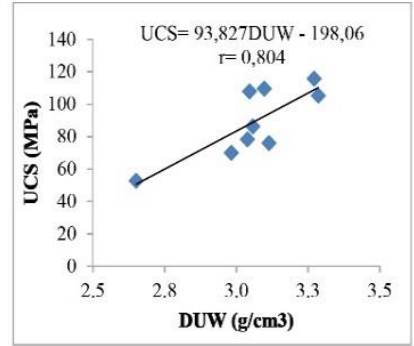

a

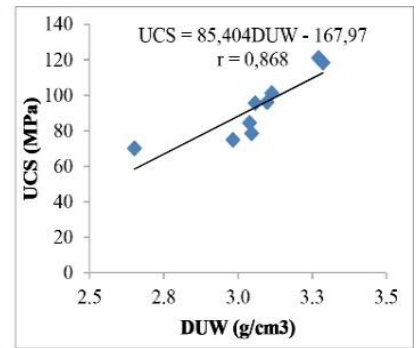

b
Figure 6. Scatter plot of UCS against Dry Unit Weight (DUW) for cubic specimens with respect to a) across foliation, b) along foliation.

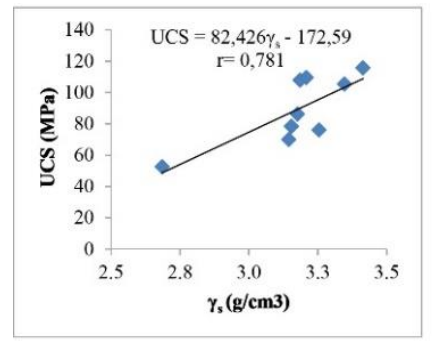

a

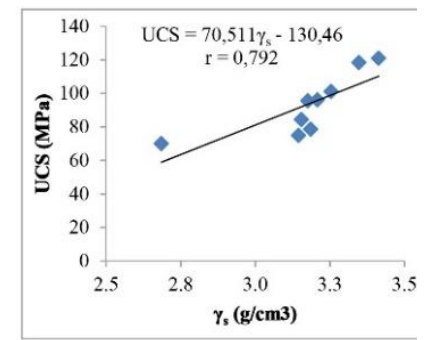

b
Figure 7. Scatter plot of UCS against Saturated unit weight $\left(\gamma_{s}\right)$ for cubic specimens with respect to a) across foliation, b) along foliation.

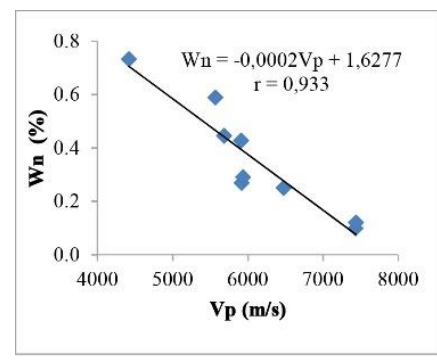

$\mathbf{a}$

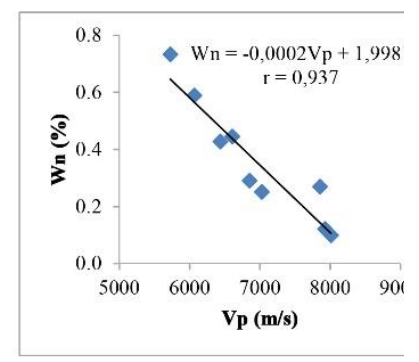

b
Figure 8. Scatter plot of Water absorption (Wn) against Vp for cubic specimens with respect to a) across foliation, b) along foliation.

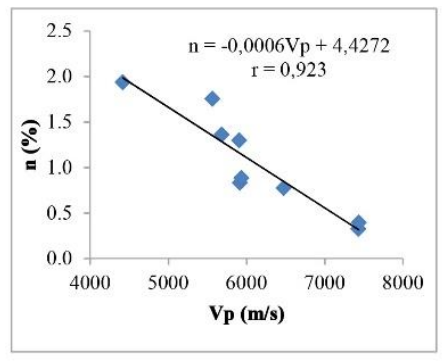

a

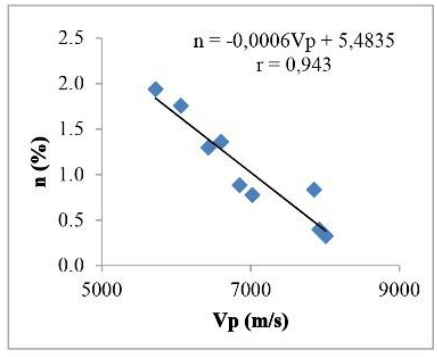

b
Figure 9. Scatter plot of Effective porosity (n) against Vp for cubic specimens with respect to a) across foliation, b) along foliation.

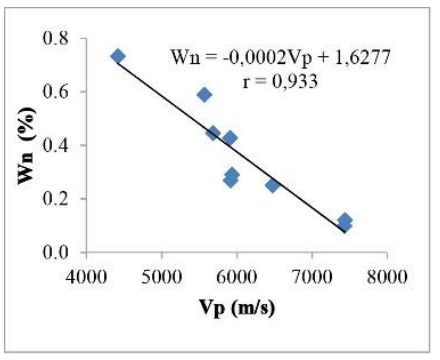

a

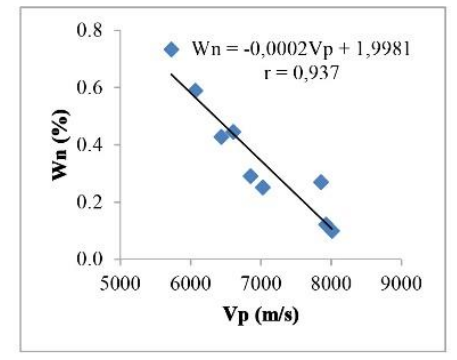

b
Figure 10. Scatter plot of Dry Unit Weight (DUW) against Vp for cubic specimens with respect to a) across foliation, b) along foliation.

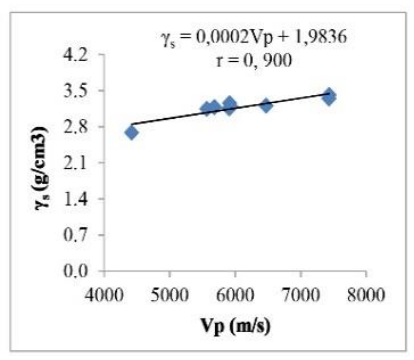

a

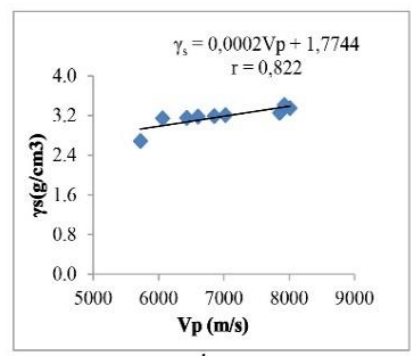

b
Figure 11. Scatter plot of Saturated unit weight $\left(\gamma_{s}\right)$ against Vp for cubic specimens with respect to a) across foliation, b) along foliation.

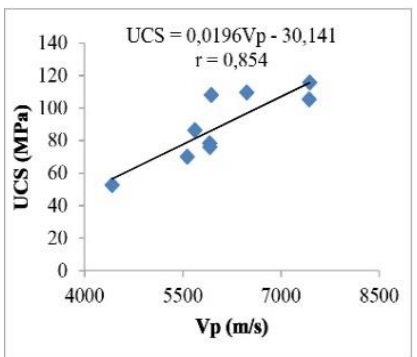

a

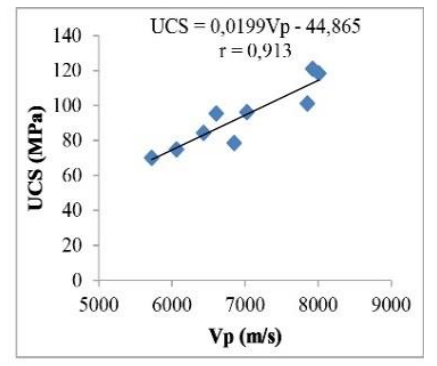

b
Figure 12. Scatter plot of UCS against Vp for cubic specimens with respect to a) across foliation, b) along foliation. 
Table 3. Empirical relationships and engineering properties obtained by laboratory studies

\begin{tabular}{|c|c|c|}
\hline Empirical Relationships & $\begin{array}{l}\text { Foliation } \\
\text { Direction }\end{array}$ & $\mathrm{r}$ \\
\hline $\mathrm{UCS}=-90,139 \mathrm{Wn}+121,36$ & $\begin{array}{l}\text { Across } \\
\text { foliation }\end{array}$ & 0,87 \\
\hline $\mathrm{UCS}=-74,898 \mathrm{Wn}+120,21$ & $\begin{array}{l}\text { Along } \\
\text { foliation } \\
\text { Across }\end{array}$ & 0,86 \\
\hline $\mathrm{UCS}=-33,170 \mathrm{n}+124,30$ & foliation & 0,86 \\
\hline $\mathrm{UCS}=-28,127 \mathrm{n}+123,26$ & foliation & 0,87 \\
\hline $\mathrm{UCS}=93,827 \mathrm{DUW}-198,06$ & $\begin{array}{l}\text { Across } \\
\text { foliation }\end{array}$ & 0,80 \\
\hline $\mathrm{UCS}=85,404 \mathrm{DUW}-167,97$ & $\begin{array}{l}\text { Along } \\
\text { foliation } \\
\text { Across }\end{array}$ & 0,86 \\
\hline $\mathrm{UCS}=82,426 \gamma_{\mathrm{s}}-172,59$ & $\begin{array}{l}\text { foliation } \\
\text { Along }\end{array}$ & 0,78 \\
\hline $\mathrm{UCS}=70,511 \gamma_{\mathrm{s}}-130,46$ & foliation & 0,79 \\
\hline $\mathrm{Wn}=-0,0002 \mathrm{Vp}+1,6277$ & $\begin{array}{l}\text { Across } \\
\text { foliation }\end{array}$ & 0,93 \\
\hline $\mathrm{Wn}=-0,0002 \mathrm{Vp}+1,9981$ & $\begin{array}{l}\text { Along } \\
\text { foliation }\end{array}$ & 0,93 \\
\hline $\mathrm{n}=-0,0006 \mathrm{~V} p+4,4272$ & $\begin{array}{l}\text { Across } \\
\text { foliation } \\
\text { Along }\end{array}$ & 0,92 \\
\hline $\mathrm{n}=-0,0006 \mathrm{Vp}+5,4835$ & $\begin{array}{l}\text { foliation } \\
\text { Across }\end{array}$ & 0,94 \\
\hline $\mathrm{DUW}=0,0002 \mathrm{Vp}+1,9229$ & foliation & 0,95 \\
\hline $\mathrm{DUW}=0,0002 \mathrm{Vp}+1,7158$ & $\begin{array}{l}\text { Along } \\
\text { foliation }\end{array}$ & 0,87 \\
\hline$\gamma_{\mathrm{s}}=0,0002 \mathrm{Vp}+1,9836$ & $\begin{array}{l}\text { Across } \\
\text { foliation } \\
\text { Along }\end{array}$ & 0,90 \\
\hline$\gamma_{\mathrm{s}}=0,0002 \mathrm{Vp}+1,7744$ & $\begin{array}{l}\text { foliation } \\
\text { Across }\end{array}$ & 0,82 \\
\hline $\mathrm{UCS}=0,0196 \mathrm{Vp}-30,141$ & foliation & 0,85 \\
\hline $\mathrm{UCS}=0,0199 \mathrm{Vp}-44,865$ & $\begin{array}{l}\text { Along } \\
\text { foliation }\end{array}$ & 0,91 \\
\hline
\end{tabular}

With this aim rock specimens were collected from 9 different locations in the investigation area and seismic and electric resistivity studies were completed at four different points (Fig. 1). Serpentinized ultrabasics at the same depth in the layer under the 4th measurement point had $\mathrm{P}$ and $\mathrm{S}$ seismic velocities of $5149 \mathrm{~m} / \mathrm{s}$ and $2628 \mathrm{~m} / \mathrm{s}$, respectively (Table 1). At the depth of these rocks, the common electric resistivity values varied from $1200 \Omega \mathrm{m}$ and $3400 \Omega \mathrm{m}$. This broad resistivity value interval is due to refractions by natural fractures or porosity in the serpentinized ultrabasic rocks in the field.

When the P seismic velocity value from the same depth layer in the field is examined, it varied between $4600 \mathrm{~m} / \mathrm{s}$ and $4700 \mathrm{~m} / \mathrm{s}$. Thus the resistivity and seismic velocity values in the field were in accordance in terms of lithology. According to the microtremor field results, the mean period was $0.1 \mathrm{~s}$, indicating compact (tight) environment and high $\mathrm{P}$ wave velocity. The broad interval calculated for horizontal/vertical (H/V) strength ratio indicated that the environmental parameters may vary with direction (anisotropic). Based on the $\mathrm{Vp} / \mathrm{Vs}$ seismic velocity ratio obtained in the field according to the table in [42] describing alteration degree, it appears that the rocks at the 1 st and 3 rd seismic measurement points were "less altered rocks", at the 2nd seismic measurement point the rocks are "very altered rocks" and the rocks at $4^{\text {th }}$ seismic measurement point were classified as "unaltered rocks". According to the table in [43], if classification according to soil-rock compaction is made, at the 1st, 3rd and 4th seismic points the rocks are "very loose" with rocks at the 2nd seismic point "compact-tight". The results of studies on the sample groups found density values varied from $2.69 \mathrm{~g} / \mathrm{cm}^{3}$ and $3.41 \mathrm{~g} / \mathrm{cm}^{3}$. Thus, as density increased, the volume (n) and weight water absorption (Wn) capacity and cavity rate reduces. The porosity values of the rock vary from 0.01 to 0.05 . In this situation, if classified according to \% porosity in [44], the rock is clearly in the "very compact" rock class. If classified according to uniaxial compressive strength as in [45], the groups perpendicular to foliation $\mathrm{A} 1, \mathrm{~B} 1, \mathrm{~B} 2, \mathrm{~B} 3$ and $\mathrm{C} 1$ and the groups parallel to foliations of A1, B1, B2, $\mathrm{B} 3, \mathrm{C} 1, \mathrm{D} 1$ and $\mathrm{G} 1$ are in the "moderate strength rock" class. From the perpendicular group D1, E1, E2 and G1 and from the parallel group E1 and E12 rock samples are in the "high strength rock" class. The compressive strength values (UCS) in the groups perpendicular to foliation varied from 52.64 $\mathrm{MPa}$ to $115.64 \mathrm{MPa}$ and in groups parallel to foliation varied from $70.04 \mathrm{MPa}$ to $121.05 \mathrm{MPa}$. This study clearly revealed that based on the data for geomechanical properties of serpentinized ultrabasic rocks, these rocks can be easily used as decorative stones, for interior-exterior decoration and in construction sector.

\section{Acknowledgements}

We would like to thank the administration of Süleyman Demirel University for supporting this work with a Scientific Research Project (3661-YL113). In addition, we are grateful to Prof. Dr. Raşit Altindağ and Research Assistant Deniz Akbay for valuable support during the laboratory study.

\section{References}

[1] Christensen NI., "Shear-Wave Vetocities in Metamorphic Rocks at Pressures to 10 Kbar." 
Journal of Geophysical Research 71, (1966) 35493556.

[2] Morgan NA., "Physical properties of marine sediments asrelated to seismic velocities", Geophysics 3 (4), (1969) 529-545.

[3] Youash Y., "Dynamic Physical Properties of Rocks: Part 2. Experimental result". Proceeding of the and Congress of the International Society for Rock Mechanic, Beograd. l, (1970) 185-195.

[4] Hamilton L., "Sound velocity density relations in sea flor sediment". J Acoustic Socam. 63, (1978) 366377.

[5] Castagna JP, Batzle ML, Eastwood RL., "Relationships between compressional-wave and shear wave velocities in clastic silicate rocks", Geophysics 50, (1985) 571-581.

[6] Ramana YV, Gogte, BS, Sarma K.., "Physical Properties of Indus Ophiolites from Kashmir Himalaya". Physics of the Earth and Planetary Interiors 43, (1986) 104-122.

[7] Chau KT, Wong RHC., "Uniaxial compressive strength and point load strength of rocks", Int. J. Rock Mech. Min. Sci. Geomech. Abstr. 33 (2), (1996) 183-188.

[8] Schön JH.,"Physical properties of rocks: Fundamentals and principles of petrophysics", Pergamon Press . (1998) 582p, London.

[9] Kahraman S., "Evaluation of simple methods for assessing the uniaxial compressive strength of rock". International Journal of Rock Mechanics and Mining Sciences 38, (2010) 981-994.

[10] Yaşar E, Erdoğan Y., " Correlation sound velocity with the density, compressive strength and Young's modulus of carbonate rocks". Int. J. Rock Mech. Min. Sci. 41, (2004) 871-875.

[11] Marinos P, Hoek E, Marinos V., "Variability of the Engineering Properties of Rock Masses Quantified by the Geological Strength Index: The Case of Ophiolites with Special Emphasis on Tunnelling". Bulletin of Engineering Geology and the Environment 65, (2006) 129-142.

[12] Vasconcelos G, Lourec OPB, Alves CSA, Pamplona J., "Prediction of the mechanical properties of granites by ultrasonic pulse velocity and Schmidt hammer hardness". North American Masonry Conference. June 3-6, St Louis, Missouri, USA (2007) 980-991.

[13] Kahraman S, Yeken T., "Determination of physical properties of carbonate tocks from P-wave velocity". Bull. Engineering Geol. Environ. 67,(2008) 227281.

[14] Ündül Ö, Tuğrul A., "Changes In Physicomechanical Properties of Ultramafic Rocks Due to Weathering, ISRM International Symposium EUROCK 2010-023, 15-18 June, Lausanne, Switzerland.

[15] Türkmen S, Tağa H, Özgüler E., "Effect of Construction Material on Dam Type Selection of the Büyük Karaçay Dam (Hatay, Turkey)” , Geotech Geol Eng 31,(2010) 1137-1149.

[16] Diamantis K, Exarhakos G, Migiros G, Gartzos E.," Evaluating the Triaxial Characteristics of Ultramafic Rocks from Central Greece Using the Physical,
Dynamic and Mechanical Properties", Open Access Library Journal 3, e3214 , (2016) 1-20.

[17] Aumento F, Loubat H., "The Mid-Atlantic Ridge Near $45{ }^{\circ}$ N. XVI. Serpentinized Ultramafic Intrusions", Canadian Journal of Earth Sciences, 8(6), (1971) 631-663.

[18] Koumantakis J., “ Compertement des peridotites et serpentinites de la Grece en travaux public. Leur propretes physiques et mechaniques". Bull. IAEG 25, (1982) 53-60.

[19] Paventi M, Scoble, M, Stead D., “ Characteristics of a complex serpentinised ultramafic rock mass at the Birchtree Mine". Manitoba. In: Mitri. H. Aubertin (Ed.) North American Rock Mechanics Symposium. Rotherdam (1996) 339-346.

[20] Escartin J, Hirth G, Evans B., "Strength of Slightly Serpentinized Peridotites: Implications for the Tectonics of Oceanic Lithosphere". Geological Society of America 29, (2001) 1023-1026.

[21] Dewandel B, Boudier F, Kern H, Warsi W, Mainprice D., "Seismic wave velocity and anisotropy of serpentinized peridotite in the Oman ophiolite". Tectonophysics 370, (2003) 77-94.

[22] Courtier AM, Hart D, Christensen NI., "Seismic properties of leg 195 serpentinites and their geophysical implications", In: Proc. ODP. Sci. Results, 195 (2004)

[23] Diamantis K., "Engineering Geological Properties of the Ultrabasic Rocks in Othrys and Kallidromo Mountains (Central Greece)". PhD Thesis, Agricultural University of Athens, Athens, 386. (2010)

[24] Özsoy EA, Yilmaz G, Arman H., "Physical, Mechanical and Mineralogical Properties of Ophiolitic Rocks at the Yakakayi Dam Site, Eskisehir, Turkey", Scientific Research and Essays 5, (2010) 2579-2587.

[25] Kurtuluş C, Bozkurt A, Endes H., “ Physical and mechanical properties of serpantinized ultrabasic rocks in NW Turkey". Pure and Applied Geophysics 169, (2012) 1205-1215.

[26] Diamantis K, Gartzos E, Migiros G., "Influence of Petrographic Characteristics on Physico-Mechanical Properties of Ultrabasic Rocks from Central Greece". Bulletin of Engineering Geology and the Environment 73, (2014) 1273-1292.

[27] Özer, P., “Güneybatı Türkiye'de Serpantinleşmiş Ultrabazik Kayaçların Fiziksel ve Mekanik Özellikleri.SDÜ Fen Bilimleri Enstitüsü, Yüksek Lisans Tezi, sayfa:76, 2015- Isparta

[28] Juteau T.,L"es ophiolites des noppes d' Antalya (Taurides occidentales, Turquie) These so Terre", Mem.No:32, 602P, 1975- Nancy.

[29] Elitok Ö., "Geology, geochemistry and geodynamic implications of the mafic-ultramafic rocks from the northern part of the Antalya Complex, SW Turkey". Tectonophysics 568, (2012) 335-356.

[30] Bozcu A, Yağmurlu F., "Eğirdir (Isparta) güneyinde yer alan Mesozoyik yaşlı birimlerin petrol jeolojisi yönünden incelenmesi”, Geosound 30, (1997) 1-9 (in Turkish).

[31] Şenel M et al., "Isparta büklümü doğusunda, otokton ve allokton birimlerin stratigrafisi (Batı Toroslar)", 
Bulletin of the Mineral Research and Exploration 118. 1996

[32] Kurtuluş C., "Sismik yöntemlerle belirlenen ampirik taşıma gücü bağıntısı ve uygulaması", Uygulamalı Yerbilimleri Dergisi Kocaeli Üniversitesi. 1 (6), (2000) 51-59.

[33] Kurtuluş C., "Sismik Arama, Teori ve Uygulama". Kocaeli Universitesi Yayınları. Kocaeli.2002.

[34] Tezcan SS, Keçeli A, Özdemir Z., "Allowable bearing capacity of shallow foundations based on shear wave velocity", Geotechnical and Geological Engineering 24, (2006) 203-218.

[35] ASTM C170/ C170M-14a., " Standard Test Method for Compressive Strenght of Dimension Stone", ASTM International, West Conshohocken, PA, 2014 www.astm.org.

[36] TS EN 1926 "Natural stone test methodsDetermination of compressive strength". TSE, 2000, Ankara.

[37] Song I, Suh, M, Yong-Kyun W, Hao T., "Determination of the elastic modulus set of foliated rocks from ultrasonic velocity measurements", Engineering Geology 72, (2004) 293-308.

[38] ISRM ., "The Complete ISRM Suggested Methods for Rock Characterization, Testing and Monitoring": 1974-2006 (Ulusay,R. and Hudson, J.A., Editors), Kozan Ofset Matbaacılık, 2007- Ankara.

[39] TS EN 1936 .,"Natural stone test methodsDetermination of real density and apparent density and of total and open porosity". TSE, 2010-Ankara.

[40] TS EN 13755., "Natural stone test methods Determination of water absorption at atmospheric pressure".2009

[41] Karpuz C, Özenoğlu A, Tutluoğlu L, Ünal E., "Rock Mechanical Principles". METU Department of Mining Engineering No: 6-7, (1986) 50-56, Ankara.

[42] Iliev IG., "An attempt to estimate the degree of weatheringof instusive rocks from their physicomechanical properties". In: Proceedings of the 1st Congrees of the International Society of Rock Mechanics Issue 3, Lisbon, (1967) 109-114.

[43] Ercan A., "Yer Araştırma Yöntemleri; Bilgiler Kurallar”. TMMOB Jeofizik Müh. Odası Yayını, 2001-Ankara

[44] Tarhan F., “ Mühendislik Jeolojisi Prensipleri”, KTÜ Yayınları, 1989-Trabzon.

[45] Deere DU, Miller RP., “ Engineering Classification and Index Properties of Rock". Air Force Weapons Laboratory, Tech. Rap. AFNL - TR- 65-116;1966New Mexico. 